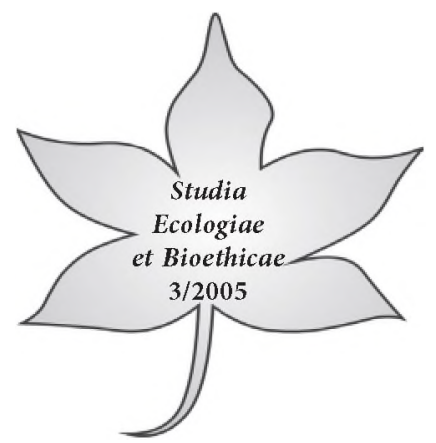

\title{
The inner workings and outer results of the therapeutic experience
}

Therapeutic closeness and encounter is essential to change in life experience and activity.

What is in the situation of therapy that makes us feel at home or close, intimate, in conversation with a therapist? On the part of the therapist, closeness to the phenomenal unfolding of the other person's world can make for a growing sensitivity in a very practical/practice way. The therapist, by being personally present to the meaning of the lived experience, by staying, keeping with the frame of reference, in a nuance, sensitive way, becomes more and more discerning, perceptive, to the other person's self-unfolding world. This staying on the experiential track is more fundamental than a cognitive, or any other aspect. We stay close to the other person, when we focus on the lived experience, and we are saying that there is there the entry to the other's world possible for us. And the paradox, here, is that we have no direct access to the other person "in her- or himself." Entering the other's world presupposes, then that this other person, the client, is really getting in touch with her or his perceptual unfolding in visual or audible zones and, consequently, is thus able to feel more and explicate more. To be more specific, this is how the therapist gets in touch with the self of the client. Through the objects within the horizon of the client's world, we grasp in our therapeutic understanding, the things of the other person's world. This grasp is the empirical grasp, the standing out, the other person's world. This grasp is the empirical grasp, the standing out, of what is encountered in the unfolding moments of openness of the other person. Van den Berg (1972) says we are already in touch with the things of the other person's world.

The therapeutic closeness, among other things, means staying phenomenally, accurately present, and, thereby, freshly manifestly open to the client's selfpresentation of the world. In other words, it is the otherness of the self of the client that we comprehend, precisely, in the client's words, in the client's responding, feelings, modes of reaction, postures, and also opinions, etc. And, on the side of the client, it is experiencing the self as, in a genuine sense, intimately entering into relation with others. 
However, it is not the primacy of feelings, as for example, Rogers' (1965) theory of client-centered therapy posited, that is the royal road to the self of the other. As we think phenomenologically, we can make a slight re-interpretation of the emphasis on feelings. And, now, we can be more specific, and articulate, about the self in the lived experience. A particular kind of intimacy of experiencing results from keeping within the frame of reference of the other, and by maintaining a precise, respectful understanding. The value of this, here, is apparently the intimate experiencing in the pathic way of living out of the experiential concerns that are emerging for the client. In facilitating such an act as a therapist, I can see, hear, that is, perceive things more accurately, only if I am really engaged in a caring way which is the field of presence.

\section{Therapeutic presence as facilitating the narrative of self-understanding}

In the field of presence, active caring makes a variety of I-am-in-experience available. This experience is reachable in the experiential sense base way of consciousness, that is, in a pathic listening rooted in earthliness as opposed to a merely conceptual or rational taking hold or apprehension of I-am-in experience, rather, it is the sensing way of consciousness, in the concrete meaning of being creatures in the world and of traveling the routes of the other, wherever they lead, in a sense this is the taking of a privileged position. The pathic way of the everyday world is more intimate and internal than any purely conceptual "model" can be. It is made possible by spontaneity, the emergence of intuition, the sense of continuity of I-am-in-experience in the primary flow of life, but other than by fusion with the client; it is truly rising to the level of co-creating an intimate "involvement" in experiences as soon as it occurs: even when we simply note their occurrence. Without any shared experience of the kind that we and others are seeking, that is, a continuity of I-am-in natural experience, one's growth and development becomes uncultivated.

The therapist moves, and can develop, more and more, the ability to remain with the concrete self-unfolding of the world of the other, as given in that firsthand self-interpretation of the other, as she or he speaks. This experience of really having someone remain very concretely and precisely in touch with the phenomenal unfolding of the person's world, is actually the very therapeutic process we are studying. This process is discerned by motives, conditions, intentional grounds and functions specifically identified by both the therapist and the client. One interesting corollary of this process is, as Eugene Gendlin (1995) observes, a particular expression of being inwardly moved, such as the eyes of the client being full of tears as he begins to cry. The initial reaction 
means the experience of being overtaken by sudden intrusion, by the rupture of consciousness with the utterances brought by the client. The client's gestural and linguistic expressions are then full and extremely vivid.

As it occurs, one needs to feel, to taste directly, so to speak, "the stimulation of a lived experience" and to work to grasp this straightforward primary inner experience. Is the client frightened, or is she or he moving in the field of possibilities? If the client does not feel deep down any movement, she or he cannot know directly the actual reality of the inner self any better. Consequently, without this, the therapist cannot come to know with more clarity the particular perspective of this person. As the client is sensitive to every aspect of reality - sight, smell, sound, and, also, feeling, predicating, valuing, purposing - she or he finds the therapist appreciative of everything that goes on in this particular world.

The disciplined therapist, like an artist, is able experientially to participate fully, as a living participant, in the proper identification or the description of the unfolding of the focal theme's personal sense as diligently as she or he can, but, also, evokes an enlivened sensitivity in the line of the conversation. The therapist attains the sense of process, of things moving, unfolding, being shaped.

To understand the subject's participation in the therapeutic process we have to look back to the time of our infancy, before even we knew words and names, to understand this kind of dedicated presence of the other person. Infancy is a period of extraordinary perception, attention wise. In the instance of infancy, the parents are intrigued watching this tiny being grow and change, are really excited while willingly helping to establish, by their support, the intimate childhood sense of I-am, or a good ego, through the enormous dedication of their subtle, loving presence. We all enjoy them, these delicate and subtle memories of reverently being watched; but with time, this extraordinary attentiveness, that we had, gradually suffers a decline. We move on to getting a very ordinary or "mere" conversational (vocal) support. For example, pictures people take of us are less and less exciting, but mostly we observe here a tranquilization, a difference in the attention paid us in our relations to others. People pay less and less attention to those gracious moments of experiencing, that would need to continue for us to have that sort of attention. In other words, the intimate sense of the self is compelled to retreat into a "subconsciousness" (Needleman, 1998, p. 127). It is only for this period in human experience that it seems to be very licit that we get extraordinary attention, along with this kind of feeling, in this kind of relationship.

Now, in the world of the adult, the psychotherapeutic situation, as it were, generally is a return to the world of the extraordinary attention we all had originally. And, the therapeutic discourse is a very kind, and pleasant, experience precisely for this reason. There is inspiration in conversation, there is relationship 
with each other, and a major work of intimacy that adds therapeutic strong points to the relationship. The therapist pays attention to the exact intonation of the client's voice, how she or he uses words, which means that the therapist respectfully assists in the client's experiential situation, to chosen language by repeating it, using, tasting, and, even, savoring it: a lovely and pleasant experience. This mode of giving attention is very precise and very concrete and is maintained continuously.

We can also observe in this eventful process of concern, of trust, of love that we are basically in an affirmative style of relating that fosters the pathic continuities of experience. For this reason, it is a very experiential process. It is the embodied experience, the directly sensed experiencing. Interestingly, and revealingly, the effect of this kind of attention is that it causes the client to pause, it slows down, and it stops the client. The situation brings her or him to a halt, at least, to a space and a time for being a more meditative person, to ponder, and to think through which enables the person to pass out of bondage to what is the present essential connectedness.

There is ultimately a mystery here. It sometimes graphically brings one to a stop, thus preparing the ground for the transformation which is taking place, the blessed moments of long awaited, yet, in a sense, unexpected transcendence, an essential change in life, a breakthrough: the act of knowing in depth the experience of life as what is at hand. In this way, the self of the client becomes anchored in the life-world.

The narrative account could not be of such dynamic value if did not include the therapist's both intuitive capacity of presence and particular focus on the ongoing understanding. In the psychological context of presence, both, the therapist and the client, come to clarity with projects in the person's involvement or projects concerning their own worlds. It is through the small re-thinking, re-imagining, re-envisioning, which are personally transformative in the area of extending the self toward other's or toward the world, and, thus, revealing, also, its, the self's, unique rebirth at the center of events, the emergence of the self to himself and its products in the shared spatio-temporal world.

The therapist's presence is then, in effect, what liberates the client from the idée fixe - fixation on a single object. Basically, this occurs by facilitating the spatio-temporal organization of the immediate experience of being in the world. The client begins to understand what the therapist is really saying; what the therapist really finds is uncovered before her or him. So this experience is given by the therapist, who really surrenders to the discipline of being effective in bringing to light unnecessary, and, usually, unneeded, and, at times, simply destructive images about the self. Next, what is planned eventually to ensue is that the client is enabled, through this intervention by the therapist, to live the present as an experience of renewed surprise about actual realities, people and situations. 
'The client doesn't need to wait, as earlier, for a desperate turning of the wheel of fortune. Living now the breakthrough, the process is enhanced, enriched, by new-found, very growth producing, possibilities of life, a sense of continuity; the sensing of a whole, and wholly harmonic, growth producing movement. The client senses this altering, not only directly psychologically, but also physically: there is "altering and one senses this altering directly and physically" (Gendlin, 1995). This gives the client a different model for living the world, a sense that there exists an inner time in which there is a future opened before her/him, as she/he discovers the sense of intimacy in each action that she or he performs or participates in. And, all of these things happen in common, ordinary, ways that now unite us, bring us closer, and not, as it was before, divide us. This entering into situations is deepened by our taking good care of connecting with those who love us. The commonplace events are then built on invitations to deepen the role of taking good care of connections with one's home, of relations with family members, and friends. At this point, it clearly shows up the inner need for establishing relations and contacts.

And, this invitation to depth is a movement to be lived in some form of being energetically involved in genuinely caring, and of being tactful, that is already full of caring. These connections in one's experiential world become vividly present in one's consciousness: we feel at a deeper feeling level what we really mean to each other.

To conclude let us say that such moments of being brought to a stand-still, or at least to a pause, of experiencing breakthrough, are absolutely necessary, internally, as well as externally, in order to grasp the crucial point of our own stories, to realize how fragile at times we are and, as well as, how brave our new insights are in our living existential drama. On the part of the therapist, it is learning how to be a kind of hovering, thinking presence, thereby fostering a kind of thoughtfulness in the therapeutic practice.

\section{The therapeutic experience: the encounter with the self as a separate being}

How the client sees it: one can learn, through her or his mundane phrases, embodied in the discourse, with the therapist genuinely weighing issues; this is pondering and a way of being present in it. At times, one phrase may reveal what we have been weighing, pondering, etc., that is what the client told us as he or she was speaking. When we repeat those phrases to the client, we are communicating concretely in a way that the other person can really see it, experience it; we are really able to manifest it to another, so that the otherness is felt. In this way, it is revealed in experience that we are thoughtfully weighing and pondering what the other person brings to us, while she or he is speaking. Again, the therapist, 
by keeping the client's frame of reference, by repeating these specific phrases communicates this experience of the self, as separate; for it is the self which is separate from every other person that she or he has ever met. One will experience in this way one's own separateness, one's own uniqueness, oneself as singular and solitary. How is this separateness coming to be recognized? This means that one begins to be more and more quiet, letting things just sit there and come into being. One enters into much more of life in which important things can happen; as she or he is quieter, more silent, in her or his living, meaning can come more easily to her or him. Here, in relating to the client, the therapist maintains the integrity and full weight of the self-descriptions and self-understandings, the self-judgments, thereby, communicating the experience of separateness, of being separate from others.

This is one reason why it is important for the client to give a narrative account, that is, to say things to an other, and this one in turn repeats, aloud, the same words. Now, how can this act of repeating out loud things to the client be therapeutic? Conceivably, when a client speaks about one's life, oneself, the understanding given by the other, the therapist, comes from what she tells. By no means, is it the opinion that the therapist can give to the other person, but rather the experience of separateness as it is embodied in such phrases as "work together but respect each other's separate identity," or "let each one of you be alone," (Gibran, 1982, p. 15) be a separate identity in the integrity of the other person, of her or his experience. Because a stance is quiet, one can become more and more free in a fresh way to everyone one knows, and, even, those one does not know, to turn one's willingness to embody evolving life-purposes and to cocreate the world in which to live.

\section{Conversation with Tania Gina: Making sense of incomplete existence}

In the conversation with Tania Gina, a special impact was made because of her professional knowledge of therapeutic issues. At some point she said: - "The therapeutic situation has made me realize not to take things for granted, as fixed or settling the matter, as finished in my life; as I see it, now, everything around me has some impact on some other things in life."

Dariusz Śleszyński: You seem to like questions, to be speaking about a certain way of living with the question, which is remarkable and leads to personal openness to things around you. Are you making a further leap and taking the risk of opening yourself to others?

Tania Gina: I learned to risk opening myself to others in group therapy. I started to do this work when I first felt that there is something deeper within me that calls for some form of living contact: my growing in sensitivity. There is something calling me to come out, to be seen not from what I was, but, rather 
from what I see in things ahead of me; as I sense them, I am trying to see myself in them.

Śleszyniski: I see there is a challenge in the call of things. I hear you saying that now your life is moving ahead, toward these other things, toward possibilities to respond to such situations.

Gina: I mean to say that the core of me is not static; it is, rather, dynamic. It is moving more and more in the directions of opening up, of seeing who I am from my experiences. I am a separate being, and being separate is not an illness; rather I see it as having possibilities of growing in sensitivity. I know that my existence is not yet complete: What I do now points to new tasks in my life and makes me realize who I can be in the future; that is, viewing my possibilities makes me realize who I can be in the future.

Śleszyniski: It is one way to see oneself as an extension of others, that is, one of the ways of having sense of rootedness in the world is seeing oneself as an extension of others. Yet, there is still more to a sense of rootedness in the world, it is for one to feel to go beyond one's self, to meet others in an attempt to be on the way to something, or to begin to create a life together. How did you come to realize that by outgrowing who you are at the moment, you create yourself, and start to know about some of your growing sensitivities?

Gina: It came to me as a discovery, a special sensitivity towards myself, that not only my life, but also the lives of others, are incomplete. And the irony here is that I will never be fully complete as an individual. When for the first time, in a group interaction, I heard the question, "will you ever be complete?" - I was a little scared. Now, since I know that I will never be fully complete as a human being, no matter what I do as a well-rounded person, I am at peace with my being - incomplete. Once I understood the reasoning behind it, the idea became clearer; then, the concept of my desires, my thinking, my feeling about myself made more sense to me. If I, in my human condition, were complete, I would have fulfilled once and for all my desires through my existence, and, then, to live the rest of my life would be boring, trite, in my day-to-day activity.

Śleszyniski: You have discovered the basic, radical, rooted meaning of incomplete human existence and you are already guided by an appreciation of the call, or existential question, that has appeared in more detailed descriptive ways in your account, that is, the way you talk about existence. More likely you have talked about, or discussed, this with others, for example, with your teachers.

Gina: Our teachers seem to know little about it. Sensitivity is a developmental concept, and it makes me feel that, as I-am-in-relating to others, I always integrate sensitivities and feelings; the incompleteness opens up in me, in coming to know myself, a new sense of relationship to myself.

Being incomplete, already happens in the world, in life, as I feel and understand it, it gives my life fervor, a different vibration in perception; there is 
an excitement I can taste in testing my abilities. I can now try new things, make mistakes, of the kind that all of us make at times, and still look forward, toward the future, for the things I want to do and to accomplish. Being incomplete makes living life worthwhile, and makes human beings strive to succeed and to make themselves better human beings.

Śleszyński: I sense, in your ways of relating, you are acting, and interacting, with others better and better as a result of a genuine concern for listening, to yourself and others. You are becoming aware by how you are organizing and integrating the situation through your sensitivity. Otherwise listening is not listening.

Gina: I certainly am into learning something from all my interactions, in new psychological contexts, and the evolving expressions that are felt to fit better the articulation of this dynamic concept in my development. Since I understand it, now I would not want to take as my project to become a complete individual, because I would squander my energy and achieve nothing.

Śleszyniski: And you, as I observe, are into having the sense of the unfolding in a real movement toward more of you and more of your energy; this movement runs against any previous, premature, self-centered conceptualizations, since this coming out, outside - as we know - is based in a primal experience of incomplete existence; the concept of incompleteness is grounded in a primal experience...

Gina: For it is because of my incompleteness that I am using all of my senses, in a genuine understanding, as I am trying to touch, taste, feel and take something as obvious, and to believe in choices made in harmony with my senses. I see in it my better me and the previous one becomes only reminiscence. I am becoming and being open to new possibilities for the future.

Śleszyński: Our incompleteness, encountered as it is giving rise to possibilities, can serve therefore as occasions to take a stance and to grow, through relating oneself freely to that which enriches our personality. We know also, as I already mentioned, that being incomplete needs to be integrated and taken up as our own, otherwise it will show up as a never ending task, that is, it belongs to the ambiguities of being, in the sense, that it enriches us when we take a stance in life.

Gina: It can mean different things, to different people. There is the condition of human existential incompleteness which can mean different things, to different people. There is the condition of human incompleteness: although we now know that no human being is ever complete, people still use the term to specify what they are missing and what they think they need in their lives. For example, for one person, a complete life would be to be a wealthy entrepreneur with a large house and fast cars. For a couple, a child would make their lives complete, so that they can feel better about themselves.

Śleszyński: It seems that underneath each situation, and even under simple inquisitiveness, or a compelling feeling to feel better about themselves, lies 
a poignant emotional need to relate to someone or something that breaths a new life in us; and under that, still, there is a feeling, a sense, of incompleteness, that seems to address the complex human reality, in a mysterious way, of the secret of our nature. And about this need to reach to the other, often foreign and mysterious for us, world, one need to look again, instead of merely dismissing, but reexamining in a spirit of looking for some new style of life or new forms of existential connections. These needs, at some point, to be looked at again, and not merely dismissed, but reexamined in a spirit of looking for some style or form of existence, although this result is not yet guaranteed.

A person may have experienced a break as a result of the pathic continuity of the experience of being broken, a break in her or his everyday presence in the world and now seeks out psychotherapy. At this point, the therapist helps to describe and live the genuine sense of painful feelings, as well as thoughts, and actions, in a special way. And the individual will not be content, in this special relationship with the therapist, merely to solve the immediate problems, but the person needs to deal with being pushed by both external and internal pain and hurt, in order to bring some closure, and make possible the pathic continuities of experience to become real in the primal flow of life; this way is the only access to the lived world. The therapy means a clarifying reestablishment of the pathic continuities of experience; the spoken articulation of that pathic content can clear a path for intimacy, a more creative way of living.

Indeed, it might be worthwhile to recognize that there is a crucial distinction between the condition of human incompleteness, with which we are endowed, and the situation of voids in our lives. This latter came about from the loss, for whatever reason, of the realizations of something important, from our life project. With an unrealized something important - as it was indicated by several of my respondents - voids come into being and with them the inability to feel filled, fulfillment. How does it happen that we deal with such a difficulty? With one of my respondents a certain undeniably important thing went into oblivion, when it appeared obvious that there was a standing commitment out there in the first place. The second respondent was aware that it became more thematic to him that there was not any easy comfort, because certain actions did not come into being, or full realization; they were without taking up a form and receiving authorship. Another noticed that some of one's tasks, or looking at this in terms of not enough nurtured and given a safe place to unfold into full awareness. What happens to the extent that we begin to have experiences such as these? We become aware of one crucial thing, namely, a blown out space in us in which everything is immersed in stagnation, and this, despite some activity related for example to performing professional function. 


\section{Cultivating bonds of relationship as source of energy and support}

Undoubtedly our narration of desire and bonds of relationship with others enable us to reorient towards what was intended to be actualized in the main areas of life and contributes to being fulfilled. Some clients say that they were "sealed off from connection," or experienced "unfilled-in gaps," due to broken continuity of growth. They recognize that they are lacking some of "the missing bits" toward wholeness of life or would like to revive the inner spirit, their sense of freedom. All of these may be indicative of voids and of lack in a certain form of fulfillment. These are recognized in reminiscing as they remember how they once were invited, or something important had been brought into existence. One of my respondents said that for some time she could not accept the blocked experience of being "held back" by such empty areas.

There exists in us a need of actual accomplishment and fulfillment that may open up important, metaphorically speaking, "flows of life." This initiates a particular personal unfolding of the self so strong that on its genuine fulfillment many individuals react with the emotions of great joy, love and regained peace. The question remains, "If there is a primary focus on life, or momentum that fills in voids, and perhaps, through revealing some painful truth of life, brings about its transformation, will this allow the individual to embrace a life-giving stance once again?"

The therapist, by mediating immediate descriptions of what fills-in gaps or what is appropriate, can encourage another's growth. The therapist participates in bringing the client to the point of breakthrough by attempting to create conditions in which they make the effort toward reaching for deeper meaning themselves.

Here is an example. A certain man, in his middle age, revealed something about his voids in life. Failure to engage deeply with everyday routines in his marriage resulted in a broken relationship. By consequence he was not with his children as they were growing through their life experiences. Then, he would not enjoy their being close to him. They have disappointed him, as he had earlier often disappointed them as their father. These major voids had irritated him, disheartened him and left him wounded. He then could not face his own fears in order to meet life's challenges as they occurred. He needed to unravel his own life mystery in order to realize the necessary breakthrough.

He was doing his work as an electrical engineer, occasionally, in his free time, writing poetry: "Now and then - he used to say - I like to write a couple of poems but never had any desire to be a writer." Some of his poems appeared in literary journals and were forgotten. One day, in his psychotherapy session, he was admitting that he would like something to leave, to give to others as a maxim. The therapist responded "Are you thinking of writing something?" "Yea, I would like 
to do it and I can do something with the fresh and intuitive language of my poetry writing." It was a big project. It required reviewing poems that had been written over many years. It also entailed the addition of new ones. It required the choosing of fitting chapter titles to sum up his experiences that would convey his personal truths in the literary images of the book. Finally it required the book title.

Interestingly, the moment when the volume of his poetry was published, he suddenly became a poet. He felt his life to be worth living. He presented to others, his readers, something tangible. At that same time he, himself began to exist. With a new potential his psychological energy began to come up with innovations. He came to a realization that he was capable of giving to others the best that was in him. It engendered an enthusiasm for life. He had a satisfaction that he arrived at this through his own effort.

This illustrates that much work transpired, and then through a simple step, at a very important breakthrough juncture, of the alternative growth producing sense of relation, connection made possible the pathic continuities of experience. The realizations occur through which the client enters into a primary flowing life, again. However this is not limited to that part of the mind that solves problems. We conclude that a breakthrough transformation not only makes self-defining possible, it also shows up as the culminating point of its growth underlying the awareness of the world that would be experienced as liberation. Liberating and transforming creativity opens up alternatives in the person's stance toward the world. What aspects of being that were quite hidden before, become transformed into a new modality of orientation. What had existed in a world that held them back now ignites in them a new imagining of the self and gives the living challenge which will "launch" them into fueling them with the questions of voids bringing at the same time other challenges for growth.

The effect of these breakthroughs was that of entering into regions of being gifted resulting from change. These phrases resonate in the gracefulness of experiencing the flow of transformations, of giving sense to what the individual in the illustration above was doing in the different areas of his life. They showed up in his job and in his relationships with his adult children. He began to consider the value of his experiences, and the impact they might have on others. He began to develop the satisfaction as a man who has accomplished something in the area of writing that would have potential for positive effect on others. In fact, he became a different person; he was able to perceive depth of being and reaching with knowing how to advance, just how to bring something to others. There was a breakthrough, transformative experience, in which having orientation in the world, respect and affirmation of others expressed in thought, word, and deed, replaced his old isolation and fear. "My actual contact, even in simple earthly things, I call now, is honest respect not only for what is out there for me, in my engagements, but also what is inside of me. What was before? It seems to me that 
my emotions were shut out and that I was "sealed off" from any connection to the rest of life." How is this person now seeing his future? Earlier he was unable to feel he was free, to take a stance, and bring about change. Now, after going through this breakthrough, he is rooted in life, he does not deny any longer the validity of emotions; especially, concerning voids, he still ponders over them for meaning in his life. "I know how it is hard to live with them waiting for something more from life."

This man recovered through the poetic process. He has done restorative living contact through his contact with reality, through the restorative vision of activating things on the basis of the intuitive level of existence. Clearly, there did appeared in him this desire for something to occur between writing poetry and him, or, as we would say, the poetic process that transformed his very self.

In psychotherapy acknowledging voids in one's life, as well as what is avoided, is really a manifestation of the estranged self, the self estranged from life, as a result of the inner anxiety and it can serve as an occasion to transform passive endurance into an active, changing, life stance. Now, the things emerge into the light of something more - to be paid attention to - and, in facing them, the stance is primarily a ready-to-meet-the-task, to feel the self moving to be filled with lived experience. The subsequent insight gained about inattention to that "out there" was the discovery of alternatives to the current situation, that lead to a life worth living. Thomas Moore (2002), a psychotherapist, rightly observes, that "Suffering and confusion are an integral part of this process, but so is joy and a certain comfort with knowing that life has not been avoided."

To sum up previous considerations, we need to state that the therapeutic relationship does not in any way make the client someone who is happy or less unhappy, or who surpasses ordinary people as they live their lives. We say this because sometimes therapy sessions make some individuals more eccentric from the common ways that have roots in a very precise and beautiful understanding of embodied spirit. Within the context of the therapeutic experience and interaction, the client becomes aware of her or his living stance while exploring ways that provide for the possibility of growth to occur - new revelations and development through healing internal structuring. 


\title{
References
}

Gendlin, E. T. (1995). Focusing-oriented psychotherapy. New York: Guilford Press.

Gibran, K, (1982). The prophet. New York: Alfred A. Knopf.

Moore, T. (2002). The soul's religion. New York: Harper Collins.

Needleman, J. (1998). Time and the soul. New York, London, Toronto: Currency/ Doubleday

Rogers C. R. (1965). Client-Centered Therapy. New York, Atlanta: Houghton Mifflin.

Schutz, A. (1962). Collected papers. Vol. 1. The Hague: Martinus Nijhoff.

ŚLESZYŃSKI, D. (2003). Interactive sources of intimacy: psychological, social, environmental. "Studia Ecologiae et Bioethicae", 1, 455-468.

ŚLEszý́sKi, D. (2004). The capacity of life to renew itself. "Studia Ecologiae et Bioethicae," 2 , in print.

ŚLeszý́ski, D. (2001). Psychology of openness. Białystok: Trans Humana University Press.

Śleszyński, D. (1997). Exploring the self in action. Białystok: Trans Humana University Press.

Van den Berg, J. H. (1972). A different existence. Pittsburgh: Duquesne University Press.

\section{Wewnętrzne oddziaływania i zewnętrzne rezultaty terapeutycznego doświadczenia}

\author{
STRESZCZENIF
}

Artykuł przedstawia i analizuje terapeutyczny dyskurs o tym, jak sytuuje się on w strukturze narratywnych odniesień wyznaczonych przez klienta, które dalej uwrażliwiają i stymulują go do stawania się bardziej świadomym, bardziej rozpoznającym i będącym bardziej w kontakcie z postrzeżeniowym ujawnianiem się świata Ja.

Terapeutyczny dyskurs czyni to na wiele sposobów, między innymi, zapośrednicza akt przełomu i alternatywny rozwój, który produkuje sens relacji, pielęgnowanie więzi i czyni możliwym patyczne ciągłości doświadczenia, rzeczywiście tak, jak one wchodzą w pierwotny strumień życia. Proces ten ma zatem charakter “doświadczeniowy”. Jest to doświadczenie ucieleśnione i bezpośrednio odczuwane. 
W terapeutycznym, pełnym wydarzeń procesie badane są unikalne i wspólne sposoby interpretacji, tak jak one kształtują relacje z innymi i z każdym z osobna. To, co pojawia się w wyniku terapeutycznej bliskości i w strukturze spotkania, staje się istotnym impulsem do zmiany życiowej aktywności. Poddano analizie i dyskusji następujące zagadnienia: (1) terapeutyczna obecność jako facylitująca narratywne rozumienie Ja klienta, (2) doświadczanie terapeutycznego spotkania z własnym, niepowtarzalnym Ja, (3) rozmowa z Giną: odnajdywanie sensu niepełnej egzystencji, (4) pielęgnowanie więzi źródłem energii i oparcia. Pojawiają się dawno oczekiwane momenty transcenencji, wychodzenia poza, kontaktowania innych jako przeobrażające i prawdziwie poszerzające Ja. 